\title{
THERMODYNAMIC PROPERTIES OF WATER DESORPTION OF SOYBEAN BRAN
}

\author{
ISABEL CRISTINA MACHADO CORRÊA* \\ CACIANO P. ZAPATA NOREÑA**
}

\begin{abstract}
The differential and integral thermodynamic properties (enthalpy, entropy, Gibbs free energy, temperature isokinetic and spreading pressure) of soybean bran were determined. Experimental data obtained from the literature was adjusted appropriately by GAB equation $\left(R^{2}>0.95\right)$, whose parameters were used to estimate the thermodynamic properties of desorption of soybean bran. The differential enthalpy and entropy increased with decreasing equilibrium moisture content and the isokinetic temperature confirmed the linear chemical compensation between the enthalpy and entropy and the process was enthalpy driven. The spreading pressure increased with increasing water activity. The integral enthalpy decreased with increasing equilibrium moisture content, whereas the integral entropy increased, but negative values, reaching up to $-0.02 \mathrm{~kJ} / \mathrm{mol} . \mathrm{K}$.
\end{abstract}

KEYWORDS: SOYBEAN BRAN; THERMODYNAMIC PROPERTIES; ISOTHERM.

\footnotetext{
* Food Engineer, Institute of Food Science and Technology, UFRGS, Porto Alegre, RS. e-mail: cristina.correa@ ufrgs.br

** Professor, Institute of Food Science and Technology, UFRGS, Porto Alegre, RS. e-mail: czapatan@ufrgs.br
} 


\section{INTRODUCTION}

The study of thermodynamic properties of food is essential to analyze water output in drying. With these properties it is possible to determine the end point of drying process, where the product is stable against reactions of deterioration, using the minimum energy required to accomplish it (AVIARA and AJIBOLA, 2002).

According to Aguerre et al. (1989), the determination of these properties are also needed to predict the kinetic parameters of sorption phenomenon and to make deductions on the microstructure and the physical changes that occur on the surface of the food product, when the rate of water sorption (adsorption or desorption) is given in terms of simultaneous process of heat and mass transfer.

Kaya et al. (2006) mention that from sorption isotherms can be calculated and predicted the major functions that quantify the enthalpies and entropies differential and integral, which are fundamental in the analysis and prediction of energy requirement and the kinetic parameters of sorption processes.

The net heat of sorption or differential enthalpy of sorption $\left(\Delta \mathrm{h}_{\mathrm{d}}\right)$ is a thermodynamic property of water sorption, which is crucial in the analysis of the phenomen of heat and mass transfer, which can determine the end point of drying and minimum amount of energy required for drying food (AVIARA and AJIBOLA, 2002). On the other hand, the differential entropy $\left(\Delta S_{d}\right)$ of a material, according to Madamba et al (1996), is proportional to the log of the number of available states corresponding to a specific energy level, and so increases with heat.

Two further parameters used to explain the modes of moisture sorption by foods are integral entropy and integral enthalpy (AL-MUHTASEB et al., 2004). The integral quantities permit qualitative interpretation of the sorption phenomen and are more descriptive of the energy relationship involved in any adsorption or desorption process. The procedure for calculation of integral functions is described by the first law of thermodynamics (RIZVI, 1986). The net integral enthalpy or net equilibrium heat of sorption indicates the binding strength of water molecules to food particles and could be a measure of the food-water affinity (AVIARA and AJIBOLA, 2004). Integral entropy describes the degree of disorder and randomness of motion of water molecules (MAZZA and LeMAGUER, 1978).

The spreading pressure is defined as the energy responsible for the diffusion of water through the pores of the material during the sorption process and it depends of the temperature and water activity.

Soybean bran is a product resulting from the extraction of oil from soybeans by mechanical and or chemical processing (BRASIL, 1993). The knowledge of thermodynamic properties is of fundamental importance for the optimization of the drying process of soybean bran, so this way it can reduce energy consumption and environmental damage (LUZ et al., 2006).

The aim of this study is to determine the thermodynamic functions (differential enthalpy, integral enthalpy, differential entropy and integral entropy) for the desorption isotherms of soybean bran.

\section{MATERIAL AND METHODS}

The thermodynamic properties for the soybean bran were calculated based on experimental data of equilibrium moisture content in function of water activity, reported by Luz et al. (2006) as seen in Table 1.

\subsection{DETERMINATION OF SORPTION ISOTHERMS}

Guggenheim-Anderson-de Boer (GAB) model was used in order to determine sorption isotherms from equilibrium water sorption data. This model is given by equation (VAN DEN BERG, 1985):

$$
X_{e}=\frac{X_{m \cdot C} \cdot k_{2} a_{w}}{(1-k \cdot a w) \cdot(1-k \cdot a w+C \cdot k \cdot a w)}
$$

Where: $X_{e}$ is equilibrium moisture content ( $\mathrm{kg}$ water/100 kg dry basis); $X_{m}$ is monolayer moisture content ( $\mathrm{kg}$ water/100 kg dry basis); $\mathrm{a}_{\mathrm{w}}$ water activity; $\mathrm{C}$ and $\mathrm{k}$ are the GAB constants. 
The goodness of fit of the developed relationship between the predicted and experimental values of equilibrium moisture content was estimated in terms of the coefficient of determination $\left(R^{2}\right)$ and relative deviation modulus percent (P) (LOMAURO et al., 1985):

$$
\mathrm{P}=\frac{100}{\mathrm{n}} \cdot \sum_{\mathrm{i}=1}^{\mathrm{n}} \frac{\left|\left(\mathrm{X}_{\mathrm{i}}-\mathrm{X}_{\mathrm{p}}\right)\right|}{\mathrm{X}_{\mathrm{i}}}
$$

where $X_{i}$ and $X_{p i}$ are the actual and predicted values of equilibrium moisture content, respectively; $n$ is the number of observations. In general, it is considered that $P$ value below $10 \%$ indicates a good fit of the experimental data (LOMAURO et al., 1985).

\subsection{DIFFERENTIAL ENTHALPY $\left(\Delta \mathbf{H}_{\mathrm{D}}\right)$}

The differential enthalpy $\left(\Delta \mathbf{h}_{\mathrm{d}}\right)$ was calculated from the equation re-arranged the ClausiusClapeyron equation (RIZVI, 1986):

$$
\left.\frac{\left[\mathrm{d}\left(\ln \left(\mathrm{a}_{\mathrm{w}}\right)\right]\right.}{\mathrm{d}(1 / \mathrm{T})}\right|_{\mathrm{Xe}_{\mathrm{e}=\mathrm{cte}}}=-\frac{\Delta \mathrm{h}_{\mathrm{d}}}{\mathrm{R}}
$$

Where $a_{w}$ is water activity; $T$ is temperature $(K) ; \Delta h_{d}$ is differential enthalpy $(\mathrm{kJ} / \mathrm{mol}) ; R$ is universal gas constant $\left(8.314 \times 10^{-3} \mathrm{~kJ} / \mathrm{mol} . \mathrm{K}\right) ; \mathrm{X}_{\mathrm{e}}$ is equilibrium moisture content $(\mathrm{kg}$ water $/ 100 \mathrm{~kg}$ dry basis)

\subsection{DIFFERENTIAL ENTROPY $\left(\Delta \mathbf{S}_{\mathrm{D}}\right)$}

Fasina et al. (1997) and Fasina et al. (1999) showed that differential entropy and enthalpy are related by equation:

$$
\ln \left(\mathrm{a}_{\mathrm{w}}\right)_{\mathrm{X}=\mathrm{cte}}=\frac{\Delta \mathrm{S}_{\mathrm{d}}}{\mathrm{R}}-\frac{\Delta \mathrm{h}_{\mathrm{d}}}{\mathrm{R}} \cdot \frac{1}{\mathrm{~T}}
$$

Thus, the differential enthalpy and entropy can be calculated from the linear regression analysis, at constant equilibrium moisture (AGUERRE et al, 1986).

TABLE 1 - EQUILIBRIUM WATER SORPTION DATA

\begin{tabular}{cccccc}
\hline & \multicolumn{2}{c}{$50^{\circ} \mathrm{C}$} & \multicolumn{3}{c}{$70^{\circ} \mathrm{C}$} \\
\hline $\mathrm{a}_{\mathrm{w}}$ & $\mathrm{x}_{\mathrm{e}}$ & $\mathrm{a}_{\mathrm{w}}$ & $\mathrm{x}_{\mathrm{e}}$ & $\mathrm{a}_{\mathrm{w}}$ & $\mathrm{x}_{\mathrm{e}}$ \\
\hline 0.111 & 0.034 & 0.110 & 0.029 & 0.109 & 0.023 \\
\hline 0.192 & 0.046 & 0.179 & 0.035 & 0.166 & 0.033 \\
\hline 0.433 & 0.068 & 0.433 & 0.078 & 0.433 & 0.141 \\
\hline 0.594 & 0.106 & 0.574 & 0.101 & 0.554 & 0.093 \\
\hline 0.744 & 0.185 & 0.741 & 0.172 & 0.738 & 0.184 \\
\hline 0.799 & 0.240 & 0.782 & 0.233 & 0.765 & 0.221 \\
\hline
\end{tabular}

Reference: Luz et al. (2006) 


\subsection{ENTHALPY-ENTROPY COMPENSATION THEORY (ISOKINETIC THEORY) AND GIBBS FREE ENERGY}

According to Leffler (1955), compensation theory proposes the following linear relationship between $\left(\Delta \mathrm{h}_{\mathrm{d}}\right)$ e $\left(\Delta \mathrm{S}_{\mathrm{d}}\right)$ :

$$
\Delta \mathrm{h}_{\mathrm{d}}=\mathrm{T}_{\beta} \cdot \Delta \mathrm{S}_{\mathrm{d}}+\Delta \mathrm{G}
$$

Where: $T_{\beta}$ is the isokinetic temperature $(K)$ and $\Delta G$ is the Gibbs free energy $(\mathrm{kJ} / \mathrm{mol})$ at $T_{\beta}$.

From a thermodynamic's viewpoint, the free energy change $(\Delta G)$ can be used as an indicative of the sorbent affinity for water, giving a criteria if water sorption is a spontaneous $(\Delta G<0)$ or non-spontaneous $(\triangle G>0$ ) process (APOSTOLOPOULOS and GILBERT, 1990).

As proposed by Krug et al. (1976) a statistical analysis test can be used to corroborate the compensation theory, by comparing $T_{\beta}$ with the harmonic mean temperature, defined as:

$$
\mathrm{T}_{\mathrm{m}}=\frac{\mathrm{n}}{\sum_{\mathrm{i}=1}^{\mathrm{n}} \frac{1}{\mathrm{~T}_{\mathrm{i}}}}
$$

Where $T_{i}$ is temperature $(K)$; $n$ is the total number of isotherms used.

\subsection{SPREADING PRESSURE ( $\Phi$ ) AND INTEGRAL ENTHALPY $\left(\Delta \mathbf{H}_{\mathbb{I N}}\right)$ AND ENTROPY $\left(\Delta \mathbf{S}_{\mathrm{IN}}\right)$}

The equation used to estimate the values of integral enthalpy and entropy is (HILL and RIZVI, 1982):

$$
\ln \left(\mathrm{a}_{\mathrm{w}}\right)_{\Phi=\mathrm{cte}}=-\frac{\Delta \mathrm{S}_{\mathrm{in}}}{\mathrm{R}}-\frac{\Delta \mathrm{H}_{\mathrm{in}}}{\mathrm{R}} \cdot \frac{1}{\mathrm{~T}}
$$

The integral enthalpy $\left(\Delta \mathrm{H}_{\text {in }}\right)$ is an integral molar quantity and it is calculated in a similar manner to the differential enthalpy, but at constant spreading pressure $(\Phi)$ instead of constant moisture content $\left(\mathrm{X}_{\mathrm{e}}\right)$ (BENADO and RIZVI, 1985).

Spreading pressure (in $\mathrm{kJ} / \mathrm{m}^{2}$ ) can be determined according to the analytical procedure described by Iglesias et al. (1976a) and Fasina et. al (1999), shown in the following equation:

$$
\Phi=\frac{K_{\text {в. }} T}{A_{m}} \cdot \int_{0}^{\text {aw }} \frac{X}{X_{m} \cdot a_{w}} \cdot d\left(a_{w}\right)
$$

Where $K_{B}$ is the Boltzmann constant $\left(1.38 \times 10^{-23} \mathrm{~J} / \mathrm{K}\right) ; A_{m}$ is the surface area of a water molecule $\left(1.06 \times 10^{-19} \mathrm{~m}^{2}\right)$ (MAZZA, 1980).

When $\mathrm{a}_{\mathrm{w}}$ tends to be zero, the integral of Equation 8 is indeterminate. Therefore, to calculate the integral of this equation, it must be considered an empirical relationship between water activity and its corresponding value of equilibrium moisture content (LI et al., 1994).

The spreading pressure at different temperatures studied has been estimated for values of water activities higher than 0.05 , using a similar equation to $G A B$ (equation 1 ):

$$
\Phi=\frac{\mathrm{K}_{\mathrm{B}} \cdot \mathrm{T}}{\mathrm{A}_{\mathrm{m}}} \cdot \mathrm{h}\left[\frac{1+\mathrm{C} \cdot \mathrm{k} \cdot \mathrm{a}_{\mathrm{w}}-\mathrm{k} \cdot \mathrm{a}_{\mathrm{w}}}{1-\mathrm{k} \cdot \mathrm{a}_{\mathrm{w}}}\right]_{0, \sigma}^{\mathrm{aw}}
$$




\section{RESULTS AND DISCUSSION}

\subsection{SORPTION ISOTHERMS}

Table 2 shows the values obtained by non linear regression of GAB model to parameters, coefficients of determination $\left(R^{2}\right)$ and relative deviation modulus percent $(P)$.

The coefficients of determination, shown values higher than 0.95 and reveals that the experimental data was well adjusted by the GAB model. In addiction, the values of relative mean deviation $(P)$, less than $5 \%$ also shown that the adjustment was appropriate. Wang and Brennan (1991) mention that $P$ values below $10 \%$ indicate a reasonable fit to the data sorption isotherms.

The acceptability of a model is not only related with the ability to fit the observed data, but also physico-chemical basis is required. The GAB model gave the important information (monolayer moisture content), since it is well known that defining $X_{m}$ and its respective water activity is important to define storage conditions (KAYA et al., 2005).

Rizvi (1986) indicated that the GAB equation describes the sorption of water of almost all foods with water activities ranging from 0 to 0.9 for having a theoretical base grounded and present three parameters, relatively simple, which have physical meaning, and be able to describe the effect of the temperature on the sorption process.

TABLE 2 - PARAMETERS OF THE GAB EQUATION OF SOYBEAN BRAN, COEFFICIENTS

OF DETERMINATION $\left(R^{2}\right)$ AND RELATIVE DEVIATION MODULUS PERCENT (P) AT

TEMPERATURES OF 50, 60 AND $70^{\circ} \mathrm{C} . \mathrm{X}_{\mathrm{M}}$ (KG WATER / KG DRY BASIS)

C AND K ARE CONSTANTS

\begin{tabular}{cccccc}
\hline & $\mathbf{X}_{\mathrm{m}}$ & $\mathbf{C}$ & $\mathbf{k}$ & $\mathbf{R}^{2}$ & $\mathbf{P}$ \\
\hline $50^{\circ} \mathrm{C}$ & 0.040 & 26.719 & 1.049 & 0.983 & 2.040 \\
\hline $60^{\circ} \mathrm{C}$ & 0.041 & 11.081 & 1.048 & 0.952 & 4.120 \\
\hline $70^{\circ} \mathrm{C}$ & 0.043 & 7.498 & 1.057 & 0.979 & 2.40 \\
\hline
\end{tabular}

Figure 1 shows the value of $X_{e}$ in relation to water activity $\left(a_{w}\right)$. It is observed that the values of equilibrium moisture content increased with water activity increase. This effect of moisture on the equilibrium water activity was also observed by Kaya et al. (2007), Cladera-Olivera et al. (2008), among other researchers.

The effect of temperature on the sorption isotherm is of great importance given that foods are exposed to different temperatures during storage and processing. It is widely accepted that an increase in temperature results in decreased equilibrium moisture content (Rizvi, 1982). The Figure 1 reveals that this behavior was verified up to a water activity of about 0.4 . Between 0.4 and $0.7 a_{w^{\prime}}$ the curves for several temperatures intersect. For water activities values higher that 0.7 , there was inversion of the effect of temperature. According to Tsami et al. (1990) this was due to an increase in solubility of sugar in water. 


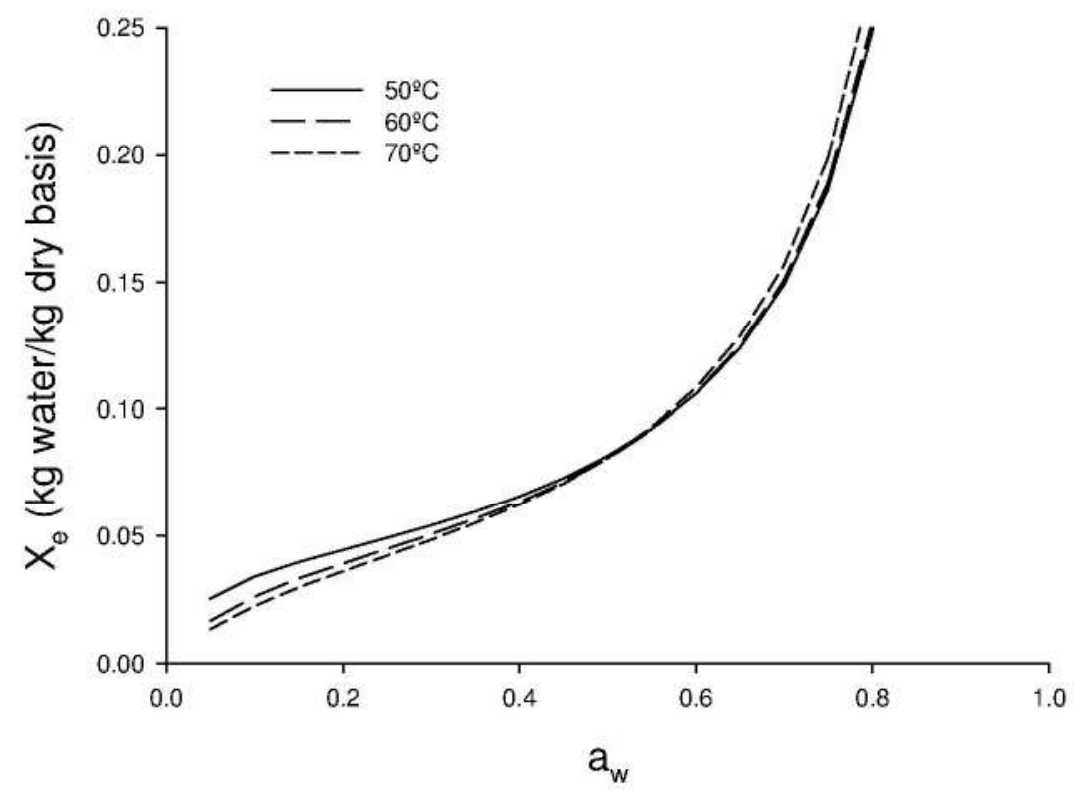

FIGURE 1 - SORPTION ISOTHERMS OF SOYBEAN BRAN AT 50,60 AND $70^{\circ} \mathrm{C}$

\subsection{DIFFERENTIAL ENTHALPY $\left(\Delta \mathrm{H}_{\mathrm{D}}\right)$ AND ENTROPY $\left(\Delta \mathrm{S}_{\mathrm{D}}\right)$}

Figure 2 reveals the relationship between the differential enthalpy and equilibrium moisture content $\left(X_{e}\right)$ for soybean bran. Increasing moisture content decreased $\Delta H_{d}$, which indicates that when smaller the equilibrium moisture content, the greater the amount of energy required to remove water molecules bounded to the structure of soybean bran due to the highly polar active sites on the surface of the product during the initial stages of sorption (at low levels of moisture). These sites are covered with water molecules, creating a monomolecular layer (Al-Muhtaseb et al., 2004). In our study, the monolayer moisture values were in the range 0.040 to $0.043 \mathrm{~kg}$ water $/ \mathrm{kg}$ dry basis. Similar results were found by Wang and Brennan (1991) to dry the potatoes into four temperature levels.

This behavior was reported from the literature in several foods (MOUSA et al., 2014; ARSLAN and TODRUL, 2005; KAYA and KAHYAOGLU, 2005 and PALOU et al., 1997). Kaya et al. (2007) when studied the thermodynamic properties of safflower petals and tarragon also observed the same behavior for the differential enthalpy. Similar behavior was also observed by Yoshida (1997) to study the drying kinetics of sweet corn.

Polatoglu et al. (2011) mention that the differential enthalpy of water is the energy required to break intermolecular forces between the molecules of water vapor and the surface of the adsorbent.

Figure 2 also shows the strong dependence of the differential entropy on moisture content, which increases with decreasing moisture. The changes in value $\Delta S_{d}$ occur due to the amount of water that is absorbed by soybean bran. The magnitude of this change varies with the vapor pressure of water in which water is absorbed. This decrease in entropy with increasing equilibrium moisture content was also reported by several researchers, among them Simal et al. (2007) in pineapples and Goneli, et al. (2010) in millet grains.

The differential entropy of a material may be related to the number of available sorption sites at a specific energy level (Madamba et al., 1996). The changes in entropy could be used in exergy balance giving valuable information about energy utilization in food processing (Rotstein, 1983). Also, the order/disorder concept useful for the interpretation of processes that take place 
during moisture sorption such as dissolution, crystallization and swelling, is related with entropy variation (AVIARA and AJIBOLA, 2002).

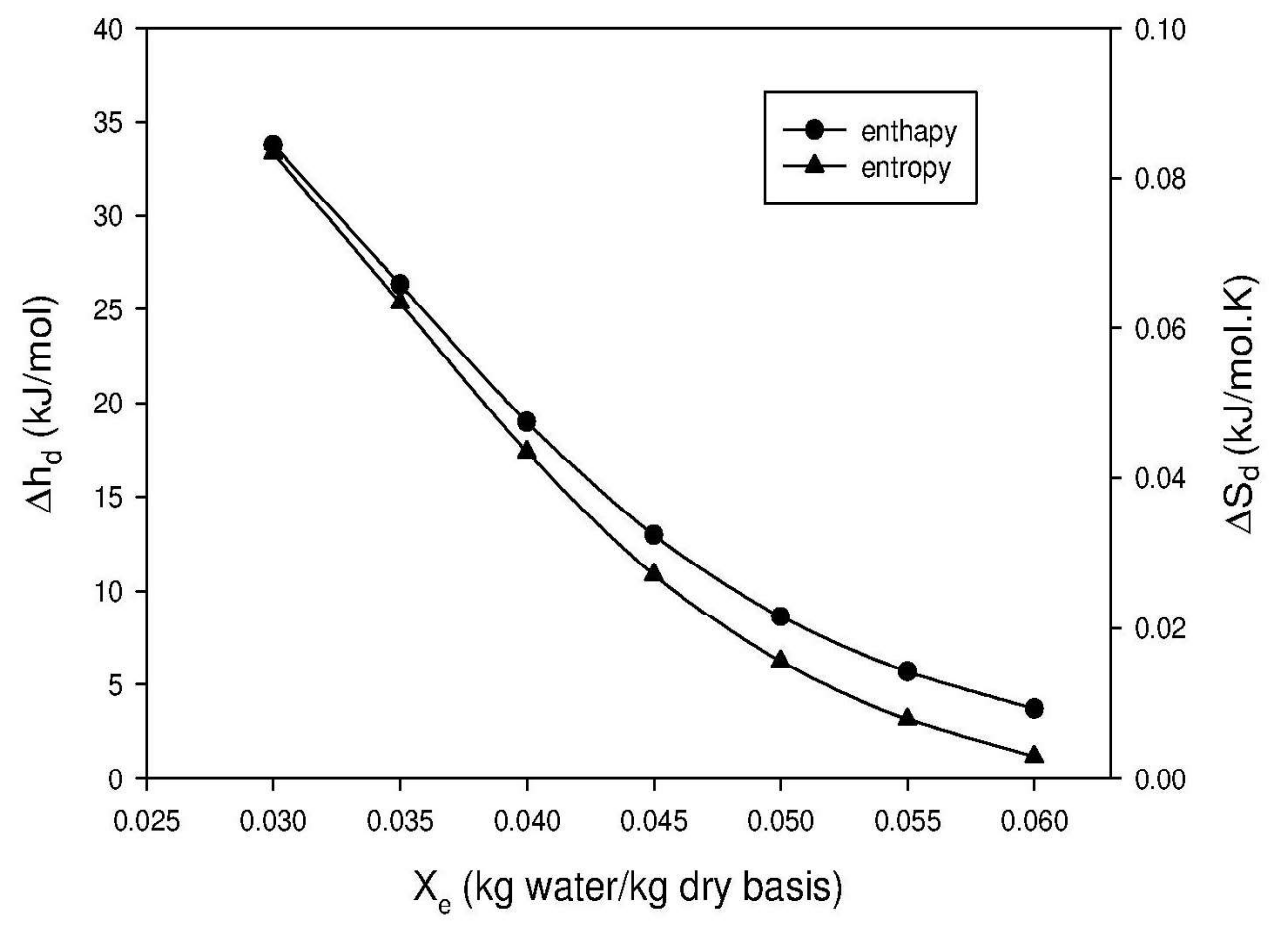

\section{FIGURE 2 - EFFECT OF MOISTURE CONTENT ON DIFFERENTIAL ENTHALPY AND ENTROPY FOR SOYBEAN BRAN}

\subsection{ENTHALPY-ENTROPY COMPENSATION THEORY}

Figure 3 shows the differential enthalpy plotted against differential entropy. As can be noted, a linear relation between these variables was obtained $\left(R^{2}=0.998\right)$, indicating that compensation chemistry between these thermodynamic parameters exists. The linear equation was:

$$
\Delta H_{d}=372.7 \Delta S_{d}+2.7535 \mathrm{R}^{2}=0.99
$$

In this equation, the slope corresponds to the isokinetic temperature soybean bran, which was $372.7 \mathrm{~K}$. This temperature was higher than the harmonic mean temperature, which was calculated by Equation 6 , resulting in a value of $332.8 \mathrm{~K}$. As $\mathrm{T}_{\beta} \neq \mathrm{T}_{\mathrm{hm}}$ confirms the linear chemical compensation (KRUG et al., 1976) between the differential enthalpy and entropy for soybean bran. Besides that, according to Leffler (1955), if $T_{\beta}>T_{h m}$ the process is enthalpy driven. Moreover, the existence of the compensation theory implies that only one reaction mechanism is followed by all the reaction series and therefore, a reliable evaluation of the isokinetic relationship aids elucidation of the reaction mechanisms (LAl et al., 2000).

The value of the free energy change $(\Delta G)$ obtained $(44.039 \mathrm{~kJ} / \mathrm{mol})$ suggests that the adsorption process is non-spontaneous ( $\Delta G>0)$, according to Apostolopoulos and Gilbert (1990). Cladera-Olivera et al. (2011) also found a non-spontaneous process in the study of adsorption of pinhão flour. 


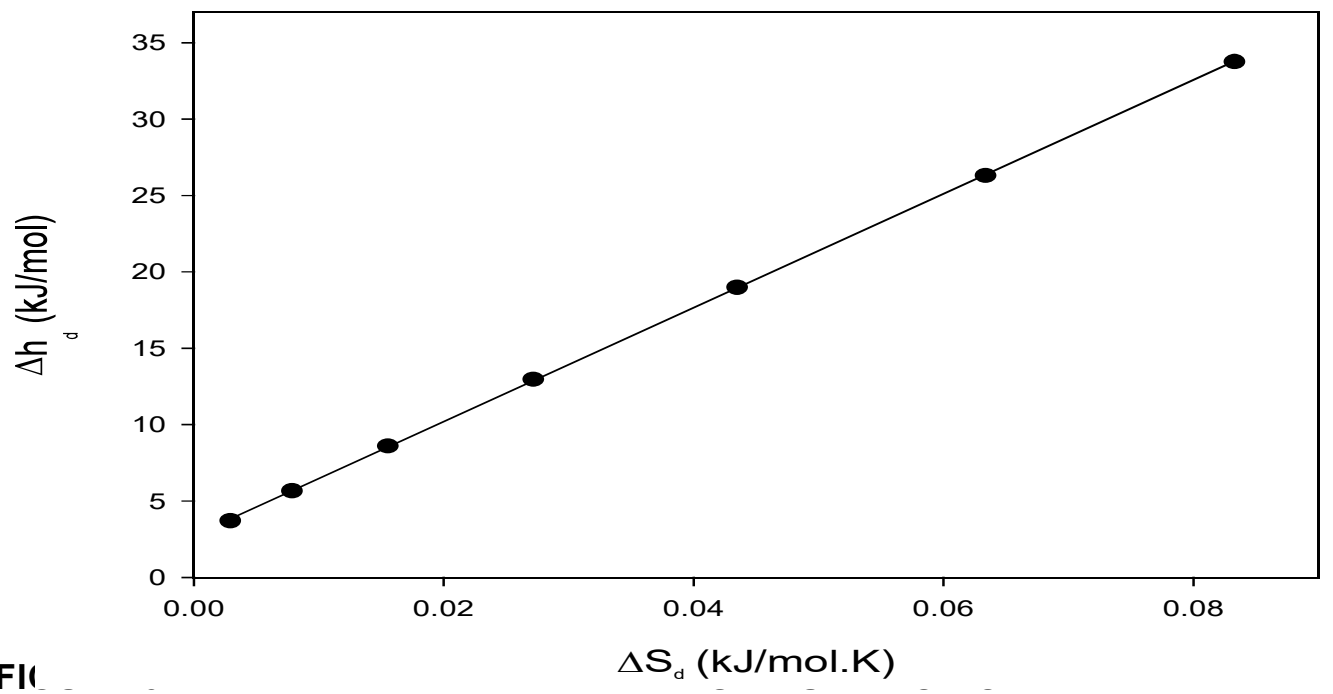

PY

FOR SOYBEAN BRAN.

\subsection{SPREADING PRESSURE ( $\Phi$ )}

Figure 4 shows that the spreading pressure increases with increasing water activity at different temperatures and decreases with increasing temperature, at a given water activity.

The values found for spreading pressure, and trends with respect to temperature and water activity, are comparable to those determined by Koua et al. (2014) for cassava, Fasina et al. (1997) for alfalfa pellets, Fasina et al. (1999) for winged bean and gari, McMinn and Magee (2003) for potato and Aviara and Ajibola (2002) for melon seed and cassava.

The spreading pressure, or surface potential, represents the surface excess of free energy, and provides an indication of the increase in surface tension of bare sorption sites due to sorbed molecules (FASINA et al., 1999)

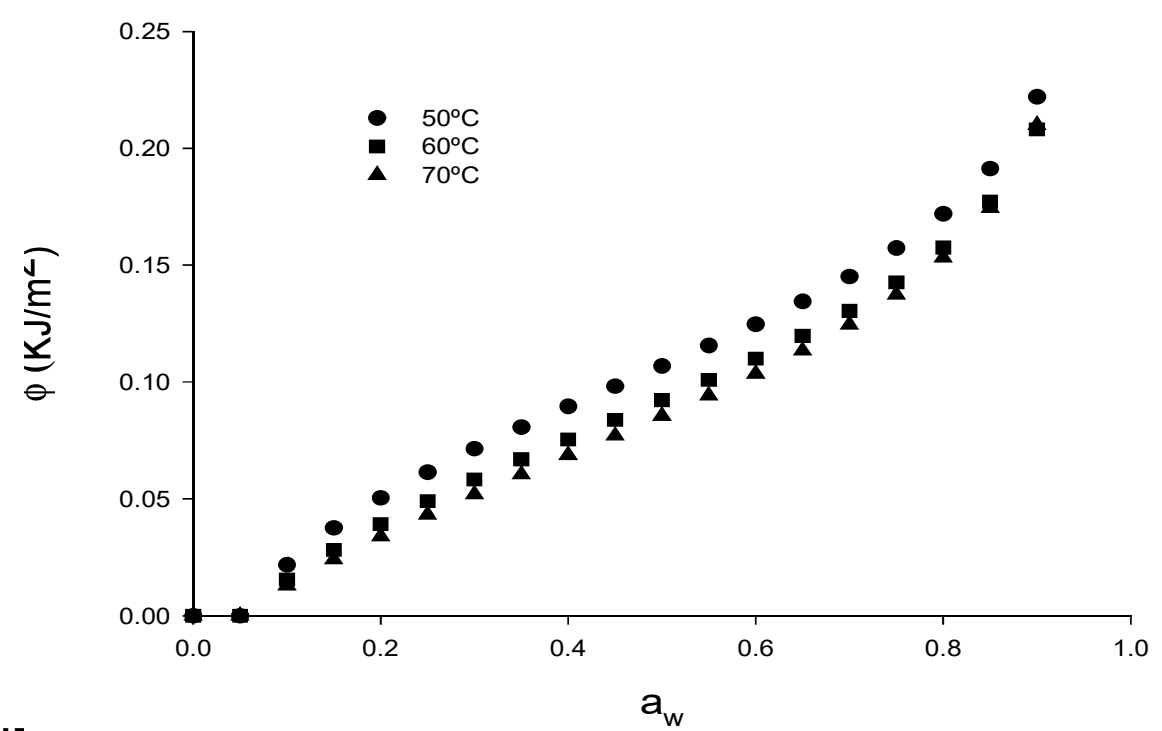

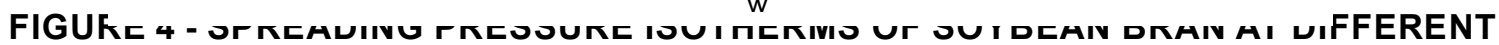




\subsection{INTEGRAL ENTHALPY $\left(\Delta \mathrm{H}_{\text {IN }}\right)$ AND ENTROPY $\left(\Delta \mathrm{S}_{\text {IN }}\right)$}

The variation of integral enthalpy with the moisture content for soybean brand is shown in Figure 5. This figure clearly shows that the integral enthalpy decreases with increasing moisture content, the trend seemed to become asymptotic. Similar trends have been reported for the integral enthalpy of melon seed (Aviara and Ajibola, 2002), beet root (IGLESIAS et al., 1976b) and rice (BENADO and RIZVI, 1985).

This thermodynamic behavior can be attributed to the monolayer covering of the materials (Fasina et al., 1999). At low moisture contents, water is adsorbed on the most accessible locations on the exterior surface of the solid. The integral enthalpy then starts to decline as less favorable locations are covered and multiple layers of sorbed water form (AL-MUHTASEB et al., 2004).

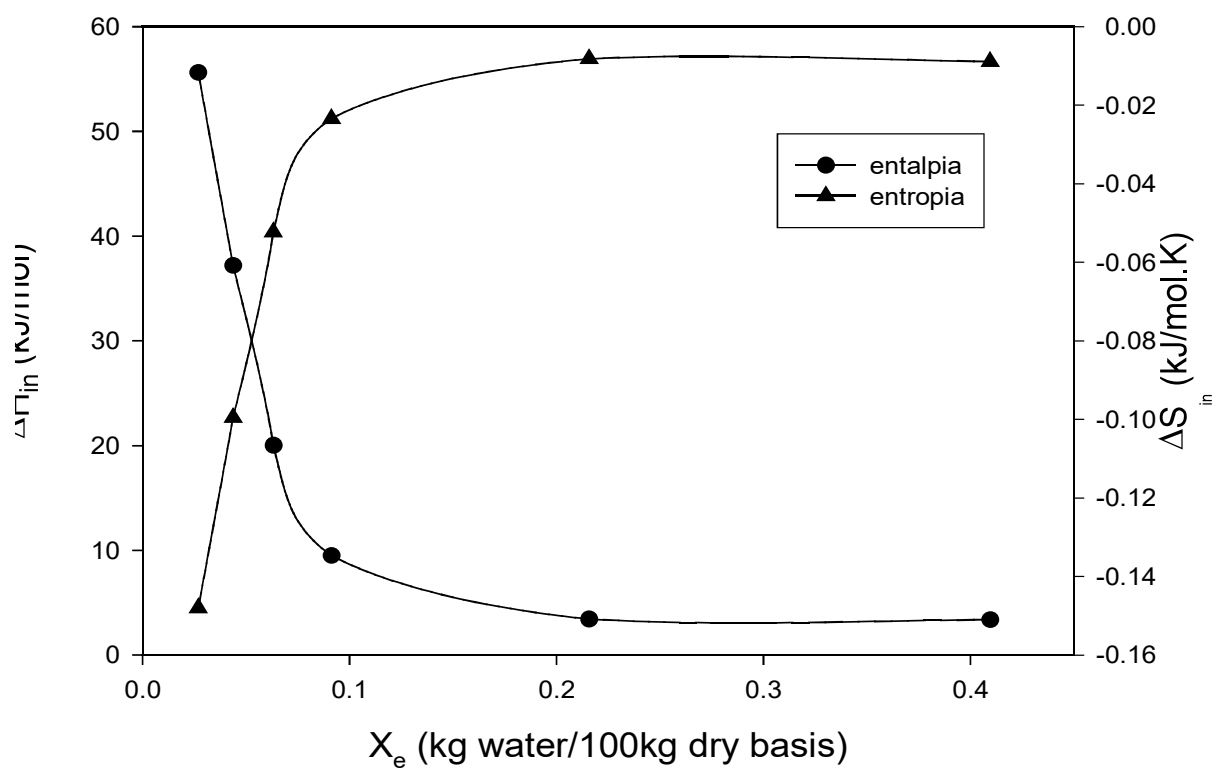

\section{FIGURE 5 - INTEGRAL ENTROPY AND ENTROPY OF SOYBEAN BRAN AS A FUNCTION OF EQUILIBRIUM MOISTURE CONTENT}

In the other hand, the integral entropy of sorbed water is negative in magnitude (Figure 5), it is observed low values of entropy in the low moisture content range, and after increasing rapidly as water covers the surface and forms further layers. As the moisture content reaches the saturation state, $\Delta \mathrm{S}_{\text {in }}$ tends towards the entropy of free water $(0 \mathrm{~kJ} / \mathrm{mol} \mathrm{K}$ ) (AL-MUHTASEB et al., 2004). Iglesias et al. (1976b) attributed the negative entropy values to the existence of chemical adsorption and/or structural modifications of the adsorbent. In addiction, Rizvi (1986) attributed this phenomenon to products that contain more polar groups, which are more strongly bounded to water.

\section{CONCLUSIONS}

The sorption data from soybean bran were well adjusted by the GAB model. Both differential enthalpy and entropy decreased with increasing moisture. The isokinetic temperature confirmed the linear chemical compensation between the enthalpy and entropy and the process is enthalpy driven. The value of the free energy change $(\Delta G)$ obtained $(44.039 \mathrm{~kJ} / \mathrm{mol})$ suggests that adsorption process is non-spontaneous $(\Delta G>0)$. The integral enthalpy increased, meanwhile, the integral entropy decreased with increasing moisture content, but with negative values for the integral entropy. 


\section{RESUMO}

\section{PROPRIEDADES TERMODINÂMICAS DE DESSORÇÃO DE ÁGUA DE FARELO DE SOJA}

As propriedades termodinâmicas diferenciais e integrais (entalpia, entropia, energia livre de Gibbs, temperatura isocinética e spreading pressure) de farelo de soja foram determinadas. Dados experimentais obtidos da literatura foram adequadamente ajustados pela equação de $G A B\left(R^{2}>0,95\right)$, cujos parâm-etros foram utilizados para estimar as propriedades termodinâmicas de dessorção do farelo de soja. A entalpia diferencial e a entropia diferencial aumentaram com a diminuição da umidade de equilíbrio e se correlacionaram entre si confirmando a teoria da compensação linear química. O spreading pressure aumentou com o aumento da atividade de água. A entalpia integral diminuiu com o aumento do teor de umidade de equilíbrio até valores próximos de $3,4 \mathrm{KJ} / \mathrm{mol}$. A entropia integral, porém, aumentou com o teor de umidade de equilíbrio, entretanto com valores negativos, alcançando valores de até $-0,02 \mathrm{KJ} / \mathrm{mol} . \mathrm{K}$.

PALAVRAS-CHAVE: FARELO DE SOJA; PROPRIEDADES TERMODINÂMICAS; ISOTERMIA.

\section{REFERENCES}

1 AGUERRE, R.J.; SUAREZ, C.; VIOLLAZ, P.Z. Enthalpy-entropy compensation in sorption phenomena: application to the prediction of the effect of temperature on food isotherms. Journal of Food Science, v.51, p.1547-1549, 1986.

2 AGUERRE, R.J.; SUAREZ, C.; VIOLLAZ, P.Z. New BET type multi-layer sorption isotherms. - Part II: Modelling water sorption in foods. LWT - Food Science and Technology, v.22, p.192-195, 1989.

3 AL-MUHTASEB, A.H.; McMinN, W.A.M.; MAGEE, T.R.A. Water sorption isotherms of starch powders. Part 2: Thermodynamic characteristics. Journal of Food Engineering, v.62, p.135-142, 2004.

4 APOSTOLOPOULOS, D.; GILBERT, S. Water sorption of coffee solubles by frontal inverse gas chromatography: Thermodynamic considerations. Journal of Food Science, v.55, p.475-477, 1990.

5 5ARSLAN, N., TODRUL, H. Moisture sorption isotherms for crushed chillies. Biosystems Engineering, v.90, n.47-61, 2005.

6 Aviara N.A.; Ajibola, O.O.; Oni, S.A. Sorption Equilibrium and Thermodynamic Characteristics of Soya Bean. Biosystems Engineering, v.87, p.179-190, 2004.

7 AVIARA, N. A.; AJIBOLA, O. O. Thermodynamics of moisture sorption in melon seed and cassava. Journal of Food Engineering, v.55, p.107-113, 2002.

8 BENADO, A.L.; RIZVI, S.S.H. Thermodynamic properties of water in rice as calculated from reversible and irreversible isotherms. Journal of Food Science, v.50, p.101-105, 1985.

9 BRASIL. PORTARIA 795: Norma de Identidade, Qualidade, Embalagem, Marcação e Apresentação do Farelo de Soja. 15/12/1993.

10 CLAdERA-OLIVERA, F.; MARCZAK, L.D.F.; NOREÑA, C.P.Z.; PETTERMANN, A.C. Modeling water adsorption isotherms of pinhão (Araucaria angustifolia seeds) flour and thermodynamic analysis of the adsorption process. Journal of Food Process Engineering, v.34, p.826-843, 2011.

11 CLADERA-OLIVERA, F.; PETTERMANN, A.C.; NOREÑA, C.P.Z.; WADA, K.; MARCZAK, L.D.F. Thermodynamic properties of moisture desorption of raw pinhão (Araucaria angustifolia seeds). International Journal of Food Science and Technology, v.43, p.900-907, 2008.

FASINA, O.O.; AJIBOLA, O.O.; TYLER, R.T. Thermodynamics of moisture sorption in winged bean seed and gari. Journal of Food Process Engineering, v.22, p.405-418, 1999.

13 FASINA, O.O.; SOKHANSANJ, S.; TYLER, R.T. Thermodynamics of moisture sorption in alfalfa pellets. Drying Technology, v.15, p.1553-1570, 1997. 
14 GONELI, A.L.D.; CORREAA, P.C.; OLIVEIRA, G.H.H.; GOMES, C.F.G., BOTELHO, F.M. Water sorption isotherms and thermodynamic properties of pearl millet grain. International Journal of Food Science and Technology, v.45, p.828838, 2010.

15 IGLESIAS, H.A.; CHIRIFE, J. Prediction of the effect of temperature on water sorption isotherms of food materials. Journal of Food Technology, v.11, p.910-917, 1976a.

16 IGLESIAS, H.A.; CHIRIFE, J.; VIOLLAZ, P. Thermodynamics of water vapour sorption by sugar beet root. Journal of Food Technology, v.11, p.91-101, 1976b.

17 KAYA, S.; KAHYAOGLU, T. Influence of dehulling and roasting process on the thermodynamics of moisture adsorption in sesame seed. Journal of Food Engineering, v.76, p.139-147, 2006.

18 KOUA, B.K.; KOFFI, P.M.E.; Gbaha, P.; Toure, S. Thermodynamic analysis of sorption isotherms of cassava (Manihot esculenta). Journal of Food Science and Technology, v.51, p.1711-1723, 2014

19 KRUG, R.R.; HUNTER, W.G.; GREIGER, R.A. Enthalpy-entropy compensation. 2. Separation of the chemical from the statistical effect. Journal of Physical Chemistry, v.80, p.2341-2352, 1976.

20 LAI, V.M.; LII, C., HUNG, W.; LU, T. Kinetic compensation in depolymerisation of food polysaccharides. Food Chemistry, v.68, p.319-325, 2000 .

21 LEFFLER, J. E. The enthalpy-entropy relationship and its implications for organic chemistry. The Journal of Organic Chemistry, v.20, p.1202-1231, 1955.

22 LI, R.; NANRI, Y.; DOUGLAS, W.J. M.; VERA, J.H. Equilibrium moisture content of cellulosic materials at high temperature. Drying Technology, v.14, p.823-847, 1994.

23 LOMAURO, C.J.; BAKSHI, A.S.; LABUZA, T.P. Evaluation of food moisture sorption isotherm equations. Part I: Fruit, vegetable and meat products. LWT - Food Science and Technology, v.18, p.112-22, 1985.

24 LUZ, G.R.; SOUZA, L.H.C.D.; JORGE, L.M.M.; PARAÍSO, P.R. Estudo das isotermas de equilíbrio do farelo de soja. Ciência e Tecnologia de Alimentos, v.26, p.408-413, 2006.

25 MADAMBA, P.S.; DRISCOLL, R.H.; BUCKLE, K.A. Enthalpy-entropy compensation models for sorption and browning of garlic. Journal of Food Engineering, v.28, p.109-119, 1996.

26 MAZZA, G., LEMAGUER, M. Water sorption properties of yellow globe onion. Canadian Institute of Food Science and Technology, v.11, p.189-193, 1978.

27 MCMINN, W.A.M.; AL-MUHTASEB, A.H.; MAGEE, T.R.A. Enthalpy-entropy compensation in sorption phenomena of starch materials. Food Research International, v.38, p.505-510, 2005.

28 McMinn, W.A.M., Magee, T.R.A., Thermodynamic properties of moisture sorption of potato. Journal of Food Engineering, 60, 157-165, 2003

29 MOUSA, W.; GHAZALI, F.M.; JINAP, S.; GHAZALI, H.M.; RADU, S. Sorption isotherms and isosteric heats of sorption of Malaysian paddy. Journal of Food Science and Technology, v.51, p.2656-2663, 2014.

30 PALOU, E.; LOPEZ, M. A.; ARGAIZ, A. Effect of temperature on the moisture sorption isotherms of some cookies and corn snacks. Journal of Food Engineering, v.31, p.85-93, 1997.

31 POLATOGLU, B.; VILDAN BES, A.; KAYA, M.; AKTAS, N. Moisture adsorption isotherms and thermodynamics properties of sucuk (Turkish dry-fermented sausage). Food and Bioproducts Processing, v.89, p.449-456, 2011.

32 RIZVI, S.S.H. Thermodynamic properties of food in dehydration. In: RAO, M. A.; RIZVI, S.S.H. Engineering Properties of Foods. New York: Marcel Dekker Inc, p.223-309, 1986

33 RIZVI, S.S.H. Thermodynamics parameters and storage stebility of drum dried peanut flakes. LWT - Food Science and Technology, v.15, p.185-193, 1982.

34 ROTSTEIN, E. Exergy balance: a diagnostic tool for energy optimization. Journal of Food Science, v.48, p.945-950, 1983

35 SIMAL, S.; FEMENIA, A.; CASTELL-PALOU, A. Water desorption thermodynamic properties of pineapple. Journal of Food Engineering, v.80, p.1293-1301, 2007.

36 TSAMI, E.; MARINOS-KOURIS, D.; MAROULIS, Z.B. Water Sorption Isotherms of Raisins, Currants, Figs, Prunes and Apricots. Journal of Food Science, v.55, p.1594-1597, 1990. 
37 WANG, N.; BRENNAN, J.G. Moisture sorption isotherm characteristics of potatoes at four temperatures. Journal of Food Engineering, v.14, p.269-287, 1991.

\section{ACKNOWLEDGMENT}

This work was supported by FAPERGS and CNPq, Brazil. 